\title{
Glucagonoma Diagnosed by Arterial Stimulation and Venous Sampling (ASVS)
}

\author{
Yukiyoshi Okauchi ${ }^{1}$, Takao Nammo ${ }^{1}$, Hiromi Iwahashi ${ }^{1}$, Takashi Kizu ${ }^{1}$, Isao Hayashi ${ }^{1}$, \\ Kohei Okita ${ }^{1}$, Kazuya Yamagata ${ }^{1}$, Sae Uno ${ }^{1}$, Fumie Katsube ${ }^{1}$, Munehide Matsuhisa ${ }^{1}$, \\ Ken Kato ${ }^{1}$, Katsuyuki Aozasa ${ }^{2}$, Tonsok Kim ${ }^{3}$, Keigo Osuga ${ }^{3}$, Shoji Nakamori ${ }^{4}$, \\ Yasuhiro Tamaki ${ }^{5}$, Tohru Funahashi ${ }^{1}$, Jun-ichiro Miyagawa ${ }^{6}$ and Iichiro Shimomura ${ }^{1}$
}

\begin{abstract}
To identify the location of pancreatic endocrine tumors, arterial stimulation and venous sampling (ASVS) is known to be useful for insulinoma and gastrinoma, but its usefulness for glucagonoma has not been verified to date. Here we report a case of glucagonoma that was diagnosed by ASVS with calcium loading, in which an approximately 6-fold increase of glucagon was observed in the splenic artery territory. MEN1 gene analysis verified the presence of a mutation and the glucagonoma was confirmed after operation. In conclusion, ASVS could be useful for the diagnosis of glucagonoma.
\end{abstract}

Key words: multiple endocrine neoplasia type 1, arterial stimulation and venous sampling, glucagonoma

(Inter Med 48: 1025-1030, 2009)

(DOI: 10.2169/internalmedicine.48.1676)

\section{Introduction}

Multiple endocrine neoplasia type 1 (MEN1) is a multiple endocrine neoplasia complex in which hyperparathyroidism caused by parathyroid hyperplasia is associated with pancreatic endocrine tumors and pituitary adenomas. The causative gene is MEN1, which exhibits an autosomal dominant pattern of inheritance. Pancreatic endocrine tumors are found in approximately $65-75 \%$ of MEN1 patients (1). Regarding pancreatic endocrine tumors, pancreatic polypeptide (PP)secreting tumors are the most common pancreatic endocrine tumor in MEN1 patients, occurring in $80 \%$ or more. They are usually accompanied by gastrinoma, while insulinoma, glucagonoma, and VIPoma are found in approximately 20\%, $3 \%$, and $1 \%$, respectively (2). Among the pancreatic endocrine tumors that occur in MEN1 patients, glucagonoma is most often malignant and thus it requires early detection and early treatment.
However, locating these tumors is not always easy. Ultrasound, CT, and MRI are the commonly used diagnostic imaging methods for pancreatic endocrine tumors, while angiography is considered the most effective method (although more invasive) for detecting such tumors since these lesions are frequently hypervascular (3). Arterial stimulation and venous sampling (ASVS) is known to be useful for localizing insulinoma and gastrinoma, with a high detection sensitivity for insulinoma being reported (4-8), but its usefulness for detecting glucagonoma has not been determined. Here, we report a case of MEN1 in which glucagonoma was located by ASVS with calcium loading.

\section{Case Report}

The patient was a 66-year-old woman with no family history of endocrine tumors. She noticed a swelling in the right anterior cervical region at the age of 38 years, but left it untreated. At the age of 52, hypercalcemia, hypophosphatemia,

\footnotetext{
${ }^{1}$ Department of Metabolic Medicine, Graduate School of Medicine, Osaka University, Suita, ${ }^{2}$ Department of Pathology, Graduate School of Medicine, Osaka University, Suita, ${ }^{3}$ Department of Radiology, Graduate School of Medicine, Osaka University, Suita, ${ }^{4}$ Department of Surgery, Osaka National Hospital, Osaka, ${ }^{5}$ Department of Breast and Endocrine Surgery, Graduate School of Medicine, Osaka University, Suita and ${ }^{6}$ Department of Internal Medicine, Division of Diabetes and Metabolism, Hyogo College of Medicine, Nishinomiya

Received for publication September 8, 2008; Accepted for publication March 13, 2009

Correspondence to Dr. Yukiyoshi Okauchi, okauchi@imed2.med.osaka-u.ac.jp
} 
Table 1. Laboratory Tests on Admission

$\begin{array}{lrlr}\text { RBC } & 431 \times 10^{4} / \mu \mathrm{L} & \mathrm{Cr} & 1.2 \mathrm{mg} / \mathrm{dL} \\ \mathrm{Hb} & 13.8 \mathrm{~g} / \mathrm{dL} & \mathrm{BUN} & 26 \mathrm{mg} / \mathrm{dL} \\ \mathrm{WBC} & 6560 / \mu \mathrm{L} & \mathrm{UA} & 5.7 \mathrm{mg} / \mathrm{dL} \\ \mathrm{Plt} & 18.7 \times 10^{4} / \mu \mathrm{L} & \mathrm{Na} & 144 \mathrm{mEq} / \mathrm{L} \\ \mathrm{FPG} & 107 \mathrm{mg} / \mathrm{dL} & \mathrm{K} & 4.1 \mathrm{mEq} / \mathrm{L} \\ \mathrm{HbA} 1 \mathrm{c} & 6.6 \% & \mathrm{Cl} & 112 \mathrm{mEq} / \mathrm{L} \\ \mathrm{IRI} & 20 \mu \mathrm{U} / \mathrm{mL} & \mathrm{Ca} & 5.2 \mathrm{mEq} / \mathrm{L} \\ \mathrm{CPR} & 5.5 \mathrm{ng} / \mathrm{mL} & \mathrm{P} & 2.4 \mathrm{mEq} / \mathrm{L} \\ \text { T-chol } & 202 \mathrm{mg} / \mathrm{dL} & \mathrm{CRP} & <0.2 \mathrm{mg} / \mathrm{dL} \\ \text { TG } & 191 \mathrm{mg} / \mathrm{dL} & & \\ \mathrm{HDL}-\mathrm{C} & 80 \mathrm{mg} / \mathrm{dL} & \text { Urinalysis } & (+-) \\ \text { LDL-C } & 163.8 \mathrm{mg} / \mathrm{dL} & \mathrm{pH} & (-) \\ \text { TP } & 6.6 \mathrm{~g} / \mathrm{dL} & \text { Protein } & (-) \\ \text { Alb } & 3.9 \mathrm{~g} / \mathrm{dL} & \text { Sugar } & (-) \\ \text { T-Bil } & 0.4 \mathrm{mg} / \mathrm{dL} & \text { Occult } & \\ \text { AST } & 13 \mathrm{U} / \mathrm{L} & \text { Acetone } & \\ \text { ALT } & 9 \mathrm{U} / \mathrm{L} & \text { Ccr } & 29.9 \mathrm{~mL} / \mathrm{min} \\ \gamma \text {-GTP } & 32 \mathrm{U} / \mathrm{L} & \text { Alb } & 29.6 \mathrm{mg} / \mathrm{day} \\ \text { ALP } & 118 \mathrm{U} / \mathrm{L} & \text { CPR } & 137.7 \mu \mathrm{gg} / \mathrm{day} \\ \text { LDH } & 248 \mathrm{U} / \mathrm{L} & & \\ & & & \end{array}$

and high plasma PTH levels were detected by a local clinic, and the patient visited our hospital the following year. Hyperparathyroidism was detected and subtotal parathyroidectomy (leaving $1 / 2$ of the upper left gland) was performed. At that time, MEN1 was suspected. Endocrinology investigations and imaging studies were performed, but no additional abnormality was found, except for PTH levels. After surgery, her $\mathrm{Ca}$ and PTH levels decreased, and the patient was discharged. From the age of 54 years, the patient began to experience backache and bone pain, and her $\mathrm{Ca}$ and PTH levels became slightly elevated. At the age of 58 , the $75 \mathrm{~g}$ OGTT was performed when the patient was admitted for investigation of her back pain, and it demonstrated a diabetic pattern. Her bone pain continued to worsen, and the patient was followed up by a local clinic. When the patient revisited our hospital at the age of 66 years, ultrasound revealed a $10 \times 8 \times 4 \mathrm{~mm}$ low echoic lesion in the dorsal part of the left lobe of the thyroid gland, and a high-intensity area was also seen on T2-weighted MR images. Blood tests revealed the following abnormal findings: Ca was $5.2 \mathrm{mEq} / \mathrm{L}$, $\mathrm{P}$ was 2.6 $\mathrm{mEq} / \mathrm{L}$, and PTH was $99.0 \mathrm{pg} / \mathrm{mL}$. The patient was admitted to our hospital in the same year for investigation and treatment.

She was $153 \mathrm{~cm}$ tall and weighed $52.8 \mathrm{~kg}$. Blood pressure was 118/60 mmHg. Physical examination revealed degradation of vibratory sensation of inferior limbs and numbness of upper and lower limbs. She had high Ca and PTH levels, a low P level, and impaired renal function (Table 1). ${ }^{99} \mathrm{mTc}-$ MIBI scintigraphy revealed an area of increased uptake in the parathyroid behind the left lobe of the thyroid gland. Since her serum levels of $\mathrm{Ca}$ and PTH were persistently elevated and renal dysfunction was observed, we considered a good indication for surgery. Endocrine studies (Table 2) revealed elevation of pancreatic endocrine hormones and abdominal imaging showed nodules $(5 \mathrm{~mm}$ and $25 \mathrm{~mm}$ in diameter) in the tail of the pancreas, suggesting the presence of pancreatic islet tumors (Fig. 1). Treatment of her hyperparathyroidism was given priority, and the patient was transferred to the Department of Endocrine Surgery for removal of the remaining parathyroid gland. Pathologic examination of the resected gland revealed hyperplasia, but no obvious malignancy. The PTH level was $157.5 \mathrm{pg} / \mathrm{mL}$ prior to surgery, and it fell to $55.1 \mathrm{pg} / \mathrm{mL}$ at 15 minutes after removal of the gland. The resected parathyroid gland measured $10 \times 9$ $\mathrm{mm}$. Part of the gland was autotransplanted into the left forearm after it had been cut into small pieces. Her serum calcium level improved to $4.8 \mathrm{mEq} / \mathrm{L}$ after surgery. The patient was subsequently transferred to our department for further testing because MEN1 was suspected.

Plain MRI of the head did not reveal any findings suggestive of pituitary adenoma. Although the basal level of GH was high, the $75 \mathrm{~g}$ OGTT caused inhibition of GH secretion, ruling out the possibility of GHoma. Plain CT of the abdomen revealed a low-density mass ( $5 \mathrm{~mm}$ in diameter) in the right adrenal gland, suggesting the presence of an adenoma. Adrenocortical and adrenomedullary hormones study showed elevated renin and aldosterone levels, but the serum and urinary levels of cortisol, adrenalin, and noradrenalin were all within the normal range or only slightly elevated. Combined with the fact that suppression of cortisol was noted in the rapid dexamethasone suppression test, the mass was concluded to be a non-functioning adrenal tumor. Her pancreatic endocrine tumor was initially suspected to be an insulinoma based on the elevated levels of IRI and CPR. When a CPR suppression test and euglycemic/hypoglycemic clamp tests were performed, suppression of CPR was insufficient. Then we planned ASVS to make a diagnosis and localize the insulinoma. In addition, because our institution had made diagnosis for glucagonoma using ASVS before (9), we planned to rule out the possibility of glucogonoma. ASVS was performed according to procedures described previously (4), and we used the criteria reported by Hayashi et al (10). We used Calcicol ${ }^{\circledR}$ (Dainippon-Sumitomo Co. Ltd., Osaka, Japan) in this case as the calcium gluconate $8.5 \%$. Calcicol ${ }^{\circledR}$ was injected as a bolus at a dose of 0.025 $\mathrm{mEq} \mathrm{Ca}{ }^{2+} / \mathrm{kg}$ body weight into each selective catheterized artery. When ASVS was performed, a selective increase of insulin was not detected, but an approximately 6-fold increase of glucagon was observed in the splenic artery territory, strongly suggesting the presence of a glucagonoma (Fig. 2). Thus, diagnostic imaging revealed multiple tumors in the pancreas ranging from 5 to $25 \mathrm{~mm}$ in diameter, and there was elevation of the basal levels of insulin, glucagon, somatostatin, and pancreatic polypeptide (PP). In addition, ASVS demonstrated elevation of glucagon in the splenic artery territory, which includes the tail of the pancreas. Based on these findings, a diagnosis of glucagonoma was suspected and laparoscopic distal pancreatectomy was performed. The resected tail of the pancreas contained tumors measuring $5 \mathrm{~mm}$ and $20 \mathrm{~mm}$ in diameter, corresponding to the lesions identified by imaging studies (Fig. 3). Partial hepatectomy was also performed because white nodules, sev- 
Table 2. Hormonal Examinations of the Present Patient

\begin{tabular}{|c|c|c|c|c|}
\hline & on admission & post operation & post Op 6 months & normal range \\
\hline GH & $6.3 \mathrm{ng} / \mathrm{mL}$ & & $3.7 \mathrm{ng} / \mathrm{mL}$ & $<6.0 \mathrm{ng} / \mathrm{mL}$ \\
\hline IGF-1 & $414 \mathrm{ng} / \mathrm{mL}$ & & & $121-436 \mathrm{ng} / \mathrm{mL}$ \\
\hline ACTH & $38.0 \mathrm{pg} / \mathrm{mL}$ & & $29 \mathrm{pg} / \mathrm{mL}$ & $<60 \mathrm{pg} / \mathrm{mL}$ \\
\hline PRL & $16.9 \mathrm{ng} / \mathrm{mL}$ & & $12.0 \mathrm{ng} / \mathrm{mL}$ & $<27 \mathrm{ng} / \mathrm{mL}$ \\
\hline LH & $22.3 \mathrm{mIU} / \mathrm{mL}$ & & $39.4 \mathrm{mIU} / \mathrm{mL}$ & 4.2-79.6 mIU/mL \\
\hline FSH & $84.3 \mathrm{mIU} / \mathrm{mL}$ & & $112.6 \mathrm{mIU} / \mathrm{mL}$ & $12.6-235.7 \mathrm{mIU} / \mathrm{mL}$ \\
\hline TSH & $2.84 \mu \mathrm{IU} / \mathrm{mL}$ & & $4.38 \mu \mathrm{IU} / \mathrm{mL}$ & $0.40-3.80 \mu \mathrm{IU} / \mathrm{mL}$ \\
\hline FT4 & $1.1 \mathrm{ng} / \mathrm{dL}$ & & $1.0 \mathrm{ng} / \mathrm{dL}$ & $1.0-1.6 \mathrm{ng} / \mathrm{dL}$ \\
\hline FT3 & $2.2 \mathrm{pg} / \mathrm{mL}$ & & $2.4 \mathrm{pg} / \mathrm{mL}$ & $2.1-3.8 \mathrm{pg} / \mathrm{mL}$ \\
\hline PTH & $113 \mathrm{pg} / \mathrm{mL}$ & $62 \mathrm{pg} / \mathrm{mL}$ & $111 \mathrm{pg} / \mathrm{mL}$ & $14-66 \mathrm{pg} / \mathrm{mL}$ \\
\hline calcitonin & $77.0 \mathrm{pg} / \mathrm{mL}$ & & $42 \mathrm{pg} / \mathrm{mL}$ & $21.6-54.0 \mathrm{pg} / \mathrm{mL}$ \\
\hline IR-glucagon & $271 \mathrm{pg} / \mathrm{mL}$ & $194 \mathrm{pg} / \mathrm{mL}$ & $214 \mathrm{pg} / \mathrm{mL}$ & $40-140 \mathrm{pg} / \mathrm{mL}$ \\
\hline FPG & $107 \mathrm{mg} / \mathrm{dL}$ & $110 \mathrm{mg} / \mathrm{dL}$ & $140 \mathrm{mg} / \mathrm{dL}$ & $70-110 \mathrm{mg} / \mathrm{dL}$ \\
\hline IRI & $20 \mu \mathrm{U} / \mathrm{mL}$ & $10 \mu \mathrm{U} / \mathrm{mL}$ & $6 \mu \mathrm{U} / \mathrm{mL}$ & $<12 \mu \mathrm{U} / \mathrm{mL}$ \\
\hline CPR & $5.5 \mathrm{ng} / \mathrm{mL}$ & $3.0 \mathrm{ng} / \mathrm{mL}$ & $2.4 \mathrm{ng} / \mathrm{mL}$ & $1.0-2.0 \mathrm{ng} / \mathrm{mL}$ \\
\hline PP & $847 \mathrm{pg} / \mathrm{mL}$ & & & $<326 \mathrm{pg} / \mathrm{mL}$ \\
\hline gastrin & $93.0 \mathrm{pg} / \mathrm{mL}$ & & & $30-150 \mathrm{pg} / \mathrm{mL}$ \\
\hline somatostatin & $18.0 \mathrm{pg} / \mathrm{mL}$ & & & $1.0-12.0 \mathrm{pg} / \mathrm{mL}$ \\
\hline cortisol & $25.2 \mu \mathrm{g} / \mathrm{dL}$ & & $14.9 \mu \mathrm{g} / \mathrm{dL}$ & $4.5-24.0 \mu \mathrm{g} / \mathrm{dL}$ \\
\hline urinary cortisol & $20.1 \mu \mathrm{g} / \mathrm{day}$ & & & $35-160 \mu \mathrm{g} /$ day \\
\hline renin activity & $4.2 \mathrm{ng} / \mathrm{mL} / \mathrm{hr}$ & & $12.1 \mathrm{ng} / \mathrm{mL} / \mathrm{hr}$ & $0.2-2.7 \mathrm{ng} / \mathrm{mL} / \mathrm{hr}$ \\
\hline aldosterone & $19.7 \mathrm{ng} / \mathrm{dL}$ & & $12.1 \mathrm{ng} / \mathrm{dL}$ & $2.0-13.0 \mathrm{ng} / \mathrm{dL}$ \\
\hline adrenaline & $0.02 \mathrm{ng} / \mathrm{mL}$ & & $0.02 \mathrm{ng} / \mathrm{mL}$ & $<0.17 \mathrm{ng} / \mathrm{mL}$ \\
\hline noradorenaline & $0.35 \mathrm{ng} / \mathrm{mL}$ & & $0.38 \mathrm{ng} / \mathrm{mL}$ & $0.15-0.52 \mathrm{ng} / \mathrm{mL}$ \\
\hline
\end{tabular}

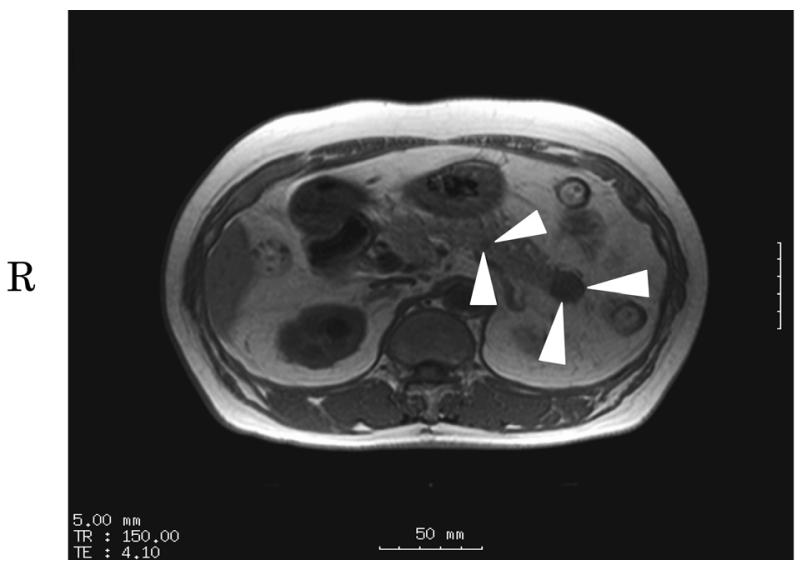

Figure 1. Abdominal MR imaging showed nodules in the pancreas (diameter $5 \mathrm{~mm}$ in body [center arrowhead], 25 $\mathrm{mm}$ in tail [end arrowhead]), suggesting the presence of pancreatic islet tumors.

eral millimeters in size, were found on the surface of the left lobe of the liver during surgery. The resected pancreatic tumors were determined to be islet cell tumors by pathologic examination. Both tumors were composed of cells with trabecular or ribbon-like proliferation, and were encap- sulated with no signs of invasion into the surrounding tissue. Immunostaining revealed numerous glucagon-positive cells, as well as some cells that were positive for insulin, somatostatin, or PP in both tumors (Fig. 4a-d). On pathological examination, the white nodules on the surface of the left lobe of the liver were shown to be regions of fibrosis and lipidosis, ruling out the possibility of liver metastasis. When endocrine studies were performed three weeks after surgery, the levels of pancreatic endocrine hormones were lower (glucagon was $194 \mathrm{pg} / \mathrm{mL}$, IRI was $10 \mu \mathrm{U} / \mathrm{mL}$, CPR was $3.0 \mathrm{ng}$ / $\mathrm{mL}$, and somatostatin was $14 \mathrm{pg} / \mathrm{mL}$ ) than before the operation. In addition, we examined MEN1 gene, after written informed consent was obtained from the patient, and c.734 delC was found at exon 4 (Fig. 5).

\section{Discussion}

Glucagonoma was first reported in 1966 by McGavran et al (11). The abnormal production of glucagon leads to a diabetic state and hypoaminoacidemia, along with symptoms such as weight loss, impaired glucose tolerance, skin rashes, mouth ulcers, and anemia. Mallinson et al referred to these symptoms as the glucagonoma syndrome (12). In the pres- 


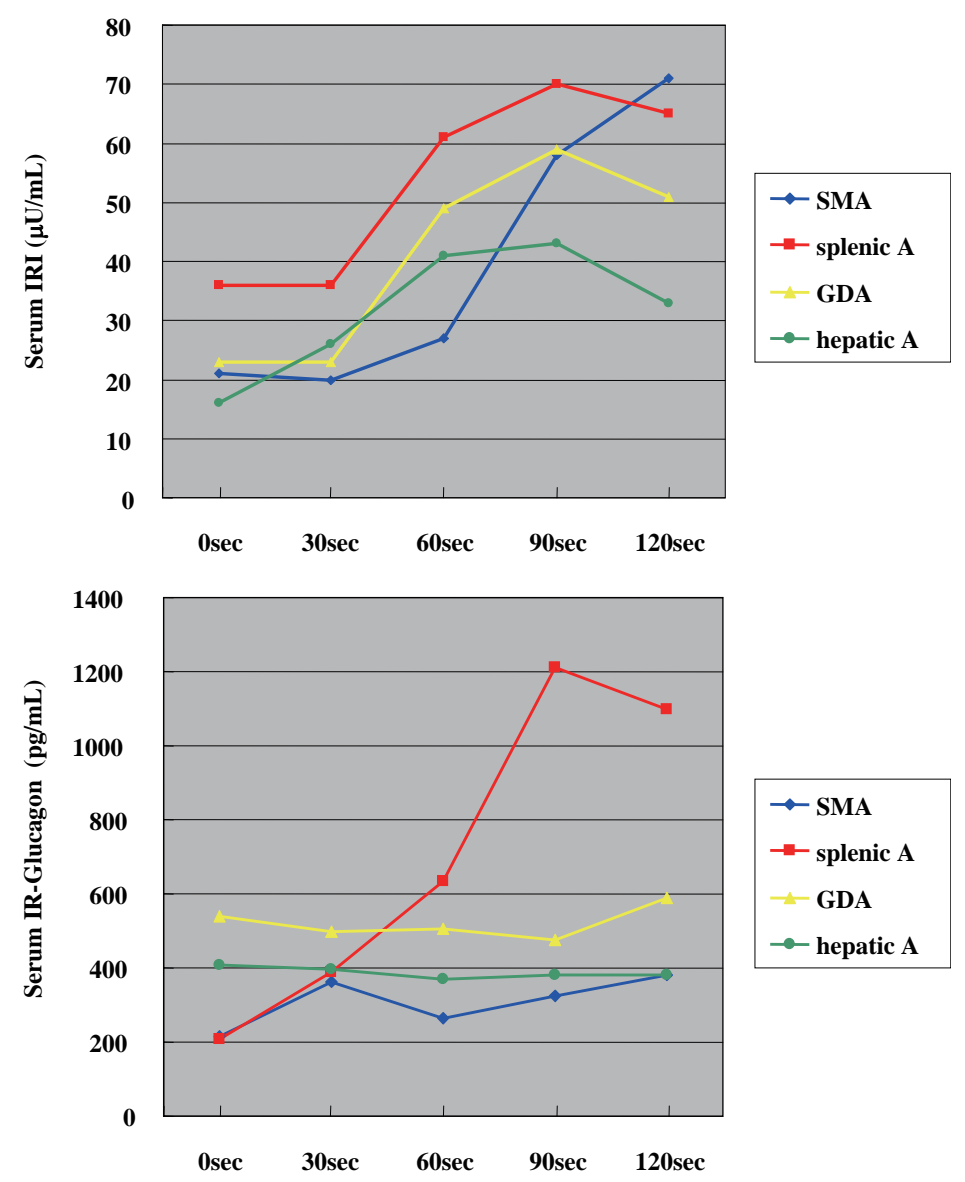

Figure 2. Results of arterial stimulation and venous sampling (ASVS) in the present case. Each line represents insulin and glucagon levels in the hepatic vein after injection of calcium gluconate $8.5 \%$ was injected as a bolus at a dose of $0.025 \mathrm{mEq} \mathrm{Ca}{ }^{2+} / \mathrm{kg}$ body weight into the gastroduodenal artery (GDA), superior mesenteric artery (SMA), splenic artery (SA), and hepatic artery (HA). A selective increase of insulin was not detected, but an approximately 6-fold increase of glucagon was observed in the splenic artery territory.

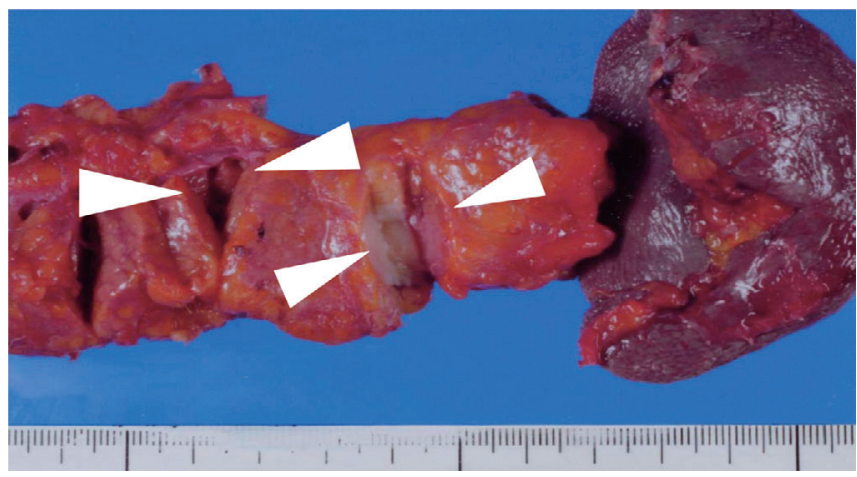

Figure 3. Macroscopic findings of the tumor. The resected tail of the pancreas contained tumors measuring $5 \mathrm{~mm}$ and $20 \mathrm{~mm}$ in diameter, corresponding to the lesions identified by imaging studies.

ent patient, recurrence of hypercalcemia and parathyroid hyperplasia were noted while the patient was being followed up after subtotal parathyroidectomy performed 13 years earlier. Further investigation revealed the presence of pancreatic endocrine tumors and an adrenal tumor, leading to the diagnosis of MEN1. Since pancreatic islet tumors are found in
$65-75 \%$ of MEN1 patients and glucagonoma is frequently malignant among these endocrine tumors of the pancreas, a differential diagnosis of pancreatic endocrine tumors is vital to facilitate early detection and early treatment. The presence of liver metastasis is considered to be the chief prognostic factor for glucagonoma. In the present case, nodules were found on the left lobe of the liver during distal pancreatectomy, but metastasis was ruled out by pathologic examination. In addition, two endocrine pancreas tumors were detected in the present case and we examined the malignancy of each tumor using Ki-67 index. We examined Ki-67 index, using a method previously reported (13), and found that the Ki-67 index was quite low. Thus the possibility of malignancy of both tumors was thought to be low (13). Nevertheless, the patient will need to be followed up with periodic imaging studies. The value of provocative tests using secretagogues for diagnosing and locating endocrine tumors is well known. Imamura and Doppman et al performed selective arterial infusion of stimulants to locate an endocrine tumor by identification of the feeding artery, and reported that gastrinoma and insulinoma could be localized by loading tests with secretin and calcium, respectively (4-8), but the 

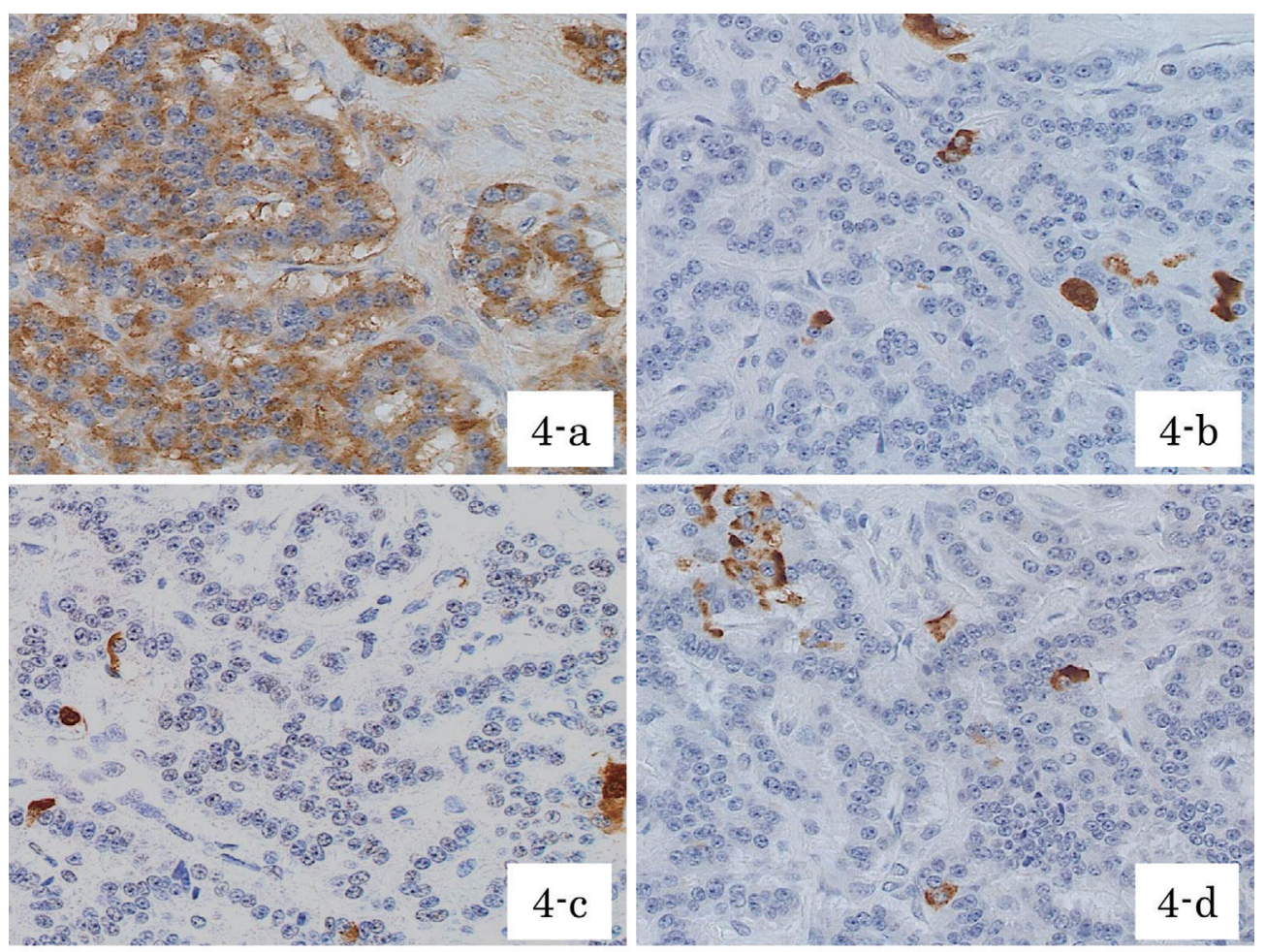

\section{(Original magnification $\times 200$ )}

Figure 4. Microscopic findings of the tumor $(20 \mathrm{~mm}$ in diameter $)(\times 200)$. Immunohistochemical staining for glucagon (4-a), insulin- (4-b), somatostatin- (4-c), or pancreatic polypeptide (PP) (4-d). Immunohistostaining revealed numerous glucagon-positive cells, as well as some cells that were positive for insulin-, somatostatin-, or PP.

\section{c.734delC}

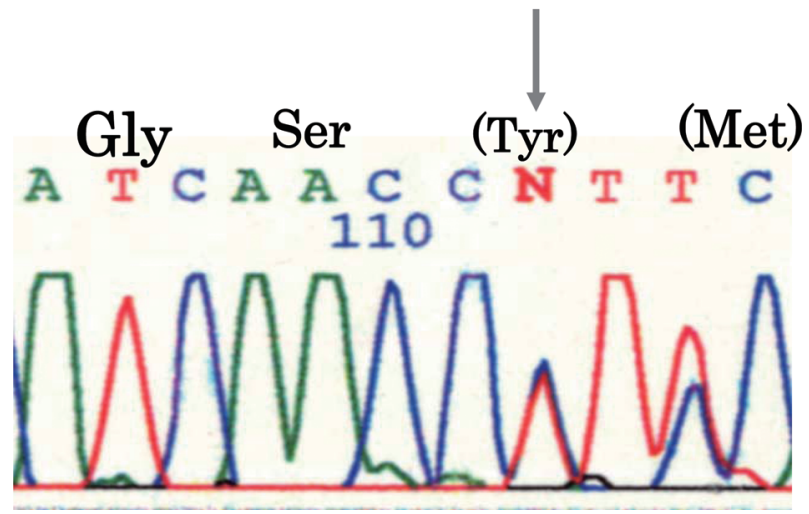

Figure 5. DNA sequence of MEN1 gene was examined in this patient. c.734delC was found at exon 4.

use of ASVS for glucagonoma has not been reported except for one case at our hospital (9). In the present case, the fasting glucagon level was $271 \mathrm{pg} / \mathrm{mL}$ (not extremely high) and skin symptoms were lacking. In addition, the patient had long-standing impaired glucose tolerance, which made secondary hyperglucagonemia and hyperinsulinemia possibility. Thus, the diagnosis of glucagonoma was difficult from only the basal values of hormones. However, ASVS revealed elevation of the glucagon level in the splenic artery territory, while insulin did not show a response suggestive of insulinoma. Our experience suggests that ASVS with calcium loading is a useful test for glucagonoma, particularly for preoperative diagnosis in patients with only a slight elevation of basal glucagon values. When the causative gene was examined in the patient, c.734delC was found at exon 4. This was the same mutation that Sato et al reported as 842 delC in 2000 (14).

\section{Acknowledgement}

We thank all members of medical staff in the Department of Metabolic Medicine and Department of Gastroenterological Surgery, Osaka University Hospital for their valuable help with this work.

\section{References}

1. Bartsch DK, Fendrich V, Langer P, Cellik I, Kann PH, Rothmund M. Outcome of duodenopancreatic resections in patients with multiple endocrine neoplasia type 1. Ann Surg 242: 757-766, 2005.
2. Doherty GM. Multiple endocrine neoplasia Type 1. J Surg Oncol 89: 143-150, 2005.

3. Doi R, Komoto I, Nakamura Y, et al. Pancreatic endocrine tumor 
in Japan. Pancreas 28: 247-252, 2004.

4. Doppman JL, Chang R, Fraker DL, et al. Localization of insulinomas to regions of the pancreas by intra-arterial stimulation with calcium. Ann Intern Med 123: 269-273, 1995 (Erratum in: Ann Intern Med 123: 734, 1995).

5. Imamura M, Takahashi $\mathrm{K}$, Adachi $\mathrm{H}$, et al. Usefulness of selective arterial secretin injection test for gastrinoma in patients with Zollinger-Ellison syndrome. Ann Surg 205: 230-239, 1987.

6. Imamura M, Hattori Y, Nishida O, et al. Unresponsiveness of insulinoma cells to secretin: significance of the secretin test in patients with insulinoma. Pancreas 5: 467-473, 1990.

7. Brandle M, Pfammatter T, Spinas GA, Lehmann R, Schmid C. Assessment of selective arterial calcium stimulation and hepatic venous sampling to localize insulin-secreting tumors. Clin Endocrinol (Oxf) 55: 357-362, 2001.

8. Tonelli F, Fratini G, Nesi G, et al. Pancreatectomy in multiple endocrine neoplasia Type 1-related gastrinoma and pancreatic endocrine neoplasias. Ann Surg 244: 61-70, 2006.

9. Yoshio N, Kitajima K, Ohsato H, et al. A case of pancreatic glucagonoma of diameter $15 \mathrm{~mm}$, discovered with medical examination and a calcium tolerance test in a selective artery was effective in preoperative diagnosis. Hormon To Rinsho (Clinical Endocrinology) 46: S156-S161, 1998 (in Japanese).

10. Hayashi T, Honda $H$, Yasumori $K$, et al. Selective intra-arterial injection of calcium for localization of insulinomas: proposed new criteria. Nippon Igaku Hoshasen Gakkai Zasshi 55: 952-956, 1995 (in Japanese, Abstract in English).

11. McGavran MH, Unger RH, Recant L, Polk HC, Kilo C, Levin ME. A glucagon-secreting alpha-cell carcinoma of the pancreas. N Engl J Med 274: 1408-1413, 1966.

12. Mallinson CN, Bloom SR, Warin AP, Salmon PR, Cox B. A glucagonoma syndrome. Lancet 2: 1-5, 1974.

13. Pelosi G, Bresaola ME, Bogina CG, et al. Endocrine tumors of the pancreas: Ki-67 immunoreactivity on paraffin sections is an independent predictor for malignancy: A comparative study with proliferating-cell nuclear antigen and progesterone receptor protein immunostaining, mitotic index, and other clinicopathologic variables. Hum Pathol 27: 1124-1134, 1996.

14. Sato M, Kihara M, Nishitani A, et al. Large and asymptomatic pancreatic islet cell tumor in a patient with multiple endocrine neoplasia type 1. Endocrine 13: 263-266, 2000.

(C) 2009 The Japanese Society of Internal Medicine http://www.naika.or.jp/imindex.html 